\title{
A look at the bright side of dance: Analysis of the relationship between dance experience, experience quality, satisfaction and word of mouth
}

Authors' Contribution: A Study Design

B Data Collection

C Statistical Analysis

D Data Interpretation

E Manuscript Preparation

F Literature Search

G Funds Collection

\author{
Metin Argan ${ }^{1}$ ACDEF, Sabri Kaya2 ADEF, Caner Özgen ${ }^{1}$ ACDEF, Gozde Yetim³ ABCDEF, \\ Alikhan Guseynov ${ }^{1}$ BF \\ ${ }^{1}$ Faculty of Sports Science, Eskisehir Technical University, Eskisehir, Turkey \\ 2 Faculty of Sports Science, Kirikkale University, Kirikkale, Turkey \\ ${ }^{3}$ School of Physical Education, Mus Alpaslan University, Mus, Turkey
}

\section{abstract}

Background: Leisure experience, including dance motivation, is one of the key factors for participation in dance events or festivals. Therefore, the experience quality that facilitates individual relationships is likely to influence the dancers' participation. The purpose of this study is to determine and to analyze dance experience motivations, experience quality, satisfaction and word-of-mouth.

Material and methods: The sample of this study consisted of 201 persons who attended the Turkey Dance Festival and who were selected by the convenience sampling method. In this study, the theoretical principles of structural equation modeling (SEM) were applied with the Amos 20 program to analyze the data.

Results: The results showed that there were significant relationships $(<0.05)$ between dance experience motivations, experience quality, satisfaction and WOM. This study results are important both as significant and practical implication for leisure managers' strategies regarding their leisure and experience motivation, and contribution to the leisure literature.

Conclusions: The findings of this study can help event managers contribute to increased participation in sustainable dance practices, and the participant-based experience value can be used as a planning tool to attract the attention of event organizers. The findings of this study also give useful insights into theoretical, practical and managerial implications for dance event organization and provide suggestions for future research.

Key words: dance; leisure; experience motivation; satisfaction; word of mouth.

\section{article details}

Article statistics:

Full-text PDF:

Received: February 2020; Accepted: March 2021; Published: June 2021

Copyright

http://www.balticsportscience.com

Indexation:

C) Gdansk University of Physical Education and Sport, Poland

Celdes, Clarivate Analytics Emerging Sources Citation Index (ESCI), CNKI Scholar (China National Knowledge Infrastructure), CNPIEC, DOAJ, EBSCO - Central \& Eastern European Academic Source, EBSCO - SPORTDiscus, EBSCO Discovery Service, Google Scholar, Index Copernicus, J-Gate, Naviga (Softweco, Primo Central (ExLibris), ProQuest - Family Health, ProQuest - Health \& Medical Complete, ProQuest - Illustrata: Health Sciences, ProQuest Nursing \& Allied Health Source, Summon (Serials Solutions/ProQuest, TDOne (TDNet), Ulrich's Periodicals Directory/ ulrichsweb, WorldCat (OCLC)

Funding: This research received no specific grant from any funding agency in the public, commercial, or not-for-profit sectors.

Conflict of interests: Corresponding author:

Open Access License:
Authors have declared that no competing interest exists.

Sabri Kaya, Kirikkale University, Faculty of Sports Science, Yahsihan Campus, Kirikkale, Turkey; phone no.: +90 318357 4242; e-mail: sabrikaya@kku.edu.tr.

This is an open access article distributed under the terms of the Creative Commons Attribution-Non-Commercial-NoDerivatives 4.0 International (https://creativecommons.org/licenses/by-nc-nd/4.0/), which permits use, distribution and reproduction in any medium, provided the original work is properly cited, the use is non-commercial and is otherwise in compliance with the license. 


\section{INTRODUCTION}

Leisure time plays an increasingly important role in our lives, because it helps to meet many needs such as avoiding stress, improving learning efficiency, and achieving a healthy mind and body balance [1]. In this sense, leisure organizations have an important place in people's daily lives. Leisure organizations are important in the tourism and hospitality sector as well as in the arts, sports, and recreation sectors. They offer different experiences to consumers. For example, cinemas, public houses, and the artificial field football matches, as well as providers of food and drink, shopping, festivals, etc., provide leisure time experiences to individuals. Therefore, leisure time can be considered as a concept that offers a wide variety of leisure experiences to individuals through numerous organizations [2]. Leisure time experience has a dynamic characteristic and is associated with individuals' emotions and moods gained from participating in these activities [3].

Additionally, Lee and Shafer [3] state that emotions are an important component of the leisure time experience or reflect the quality of the leisure participants' experience, and therefore, leisure participants experience is dynamic. People can enjoy leisure time while relaxing, having fun or even participating in recreational activity. This experience can be realized by passive or active participation. For example, while watching a movie in a cinema is passive participation, eating at a restaurant can be considered as active participation [4]. Similarly, an individual's participation in a recreational activity can be considered as active one. Therefore, this study discusses the experiences of active participants in a dance festival. In this context, the relationships between experience motivations, experience quality, satisfaction and word of mouth communication (WOM) are examined. Although there are various studies related to experience in the literature, in fact, there is hardly any research related to dance that makes this study important in terms of contribution to the leisure time literature.

\section{THEORETICAL BACKGROUND AND HYPOTHESES}

\section{Dance}

Dance is a rhythmic body movement, usually to music and within a given space to express an idea or emotion, release energy, or simply take delight in the movement itself. Dance is a performing art form consisting of purposefully selected sequences of human movement. This movement has an aesthetic and symbolic value, and it is acknowledged as dance and a way of dealing with feelings and releasing them by performers and observers within a particular culture. It means that dance is an art form or activity that utilizes the body and the range of movement of which the body is capable [5].

Of course, dance may be made up of movements associated with many activities, as in the work dances common to many cultures, and it may even accompany such activities. But even in the most practical dances, movements that make up the dance are not reducible to those of straightforward labor; they rather involve some extra qualities such as selfexpression, aesthetic pleasure, and entertainment. Positive effects on the people's mood as a result of dancing include improved psychological wellbeing, as well as greater selfesteem and confidence, which leads to an improved social life, whose benefit cannot be underestimated when it comes to overall health and quality of life. Additionally, whilst the physical movement of dance helps reduce stress, anxiety and depression, dancing with others also helps us feel more connected and social. Dance classes can encourage social bonds and friendships which are key factors in improving our mood and mental health. There is no doubt that any dance is a brilliant form of exercise. Moving the body in all directions for an extended period of time with all the enthusiasm one can muster is great for improving one's physical health. 


\section{Experience Motivation}

Participation in a recreational activity depends on personal preferences, but motivation is the most essential element of the participation, because motivation is a driving power towards the intended behavior. Thus, it helps to understand and analyze why an individual participates in recreational activities [6]. According to the Freudian theory, all human behavior is motivated; namely, even random behavior and subconscious desires and intentions affect behavioral motivation of individuals. Therefore, in motivation theories, needs such as psychological requirements and search for satisfaction play an important role [7].

An individual who wants to participate in a recreational activity might have internal and external experience motivation [8]. Internal experience motivations include factors such as pleasure, challenge, skill development and mastering, while external experience motivations include factors such as reward, improved health and physical appearance [9]. In the Leisure Motivation Scale (LMS) developed by Beard and Ragheb [10], motivations for participation in recreational activity are classified as intellectual, social, competence/mastery and avoiding stimulus. While intellectual dimension includes mentally encouraging activities such as learning, discovering, creating and imagining, it also evaluates how motivated individuals are to participate in leisure time activities. On the other hand, social dimension defines at what level individuals are involved in leisure activities due to social reasons and it evaluates two basic needs: need for interpersonal relationship and need for respect from others. The Competence/Mastery level evaluates the level of participation in leisure activities in order to succeed, master, struggle and compete during physical activity. Avoiding stimulus evaluates motivation to participate in leisure activities to avoid daily activities. Avoiding social contact is related to recreational activities to relax and rest [11]. In the relevant literature there are various studies investigating motivation to participate in recreational activity. For example, Ho et al. [12] stated that internal motivations of individuals that ride a bicycle for recreational purposes were competence, loneliness, physical challenge, adventure experience, and search for encouragement, social encounters and escape.

Additionally, Lee and Ewert [13] stated that socialization, entertainment, self-identity and freedom search, target success and escape were reasons for participation in recreational activity. Also, Sheng and Chen [14] studied experience expectations and found five dimensions which were comfort-entertainment, cultural entertainment, personal identity, past memories and escape. Similarly, Altunel [15] found four dimensions - past memories, escape, personal identity and desire to learn in experience expectations. Therefore, it could be stated that internal or external experience motivation is important for individuals to participate in recreational activities. Accordingly, this study analyzed experience motivations of individuals that participated in a dance festival for recreational purposes.

\section{Experience Quality}

Experience can be defined as entertaining, interesting and unforgettable moments achieved by an individual from an activity as well as life that is repeated by telling and spread joyfully from mouth to mouth [16]. Quality is defined as superiority or excellence, and perceived quality is a customer's judgment of the overall quality of an object $[17,18]$. On the other hand, experience quality is total satisfaction of individuals perceived from activities. Various satisfaction scales include statements to measure the quality of activity rather than individuals' satisfaction with the activity [19]. Experience quality is related to an individual's feeling of enjoyment or boredom during recreational activity experience. In other words, experience quality refers to judgment during or after experienced activity. For example, an individual's general judgment about the quality of a concert or a football game watched on television with his/her friends is related to the perceived experience quality [20]. Lemke et al. [21] characterize experience quality as perceived perfection or superiority from the obtained experience. Similarly, Paul and Ponnam [22] found that consumer experience 
quality has a positive relationship with the value provided by individuals at a service or product purchasing point. Driver and Tocher [23] stated that recreational activity experiences include experience obtained by individuals from activities, entertainment, individual feedback and selection of activities they are interested in with freewill.

It could be stated that the perceived experience quality and experience motivation from activities are important for these selections. With this in view, there are supportive studies in the literature. Ahmed et al. [24] determined that service quality has a significant effect on individual motivation and satisfaction. Sobral [25] stated that motivation is significantly related to students' class quality perception. Kılıç and Keklik [26] found a high-level relationship between factors that increase work life quality and motivation. Sasongko [27] showed that employee motivation is an effective predictor of service quality performance. Subrahmanyam [28] found that service quality directly and indirectly affected students' satisfaction-based motivation. Accordingly, the following hypothesis is suggested:

\section{H1: There is a significant relationship between experience motivation and experience quality.}

\section{Satisfaction}

Satisfaction reflects how much an individual is pleased with recreational activity experience. In other words, this term can be expressed as positive perception or emotions that emerge as a result of participation in leisure activity [29]. Individuals can achieve leisure time satisfaction with leisure time selection, and leisure time satisfaction can be measured by meeting individual needs in conscious or unconscious way [1]. Therefore, leisure time satisfaction can be evaluated as a concept related to what individuals do during leisure time experience and as a concept driven from leisure time participation that analyzes whether needs are met [30]. Satisfaction is an emotion that emerges from individuals' participation in recreational activity and it can be considered with regard to external and internal factors. While external factors help understand leisure time resources, it is possible to say that internal factors measure leisure time satisfaction more accurately, because internal factors analyze a positive perception based on individuals' leisure time participation and the extent to which they satisfied with leisure time experience [30]. Therefore, satisfaction contains psychological, physiological, social, educational, relaxing and aesthetic sub-dimensions. Based on these dimensions, individuals evaluate whether their personal needs are met after participation in leisure activity or how much they were satisfied [29]. These dimensions are included in the Leisure Satisfaction Scale (LSS) developed by Beard and Ragheb [31]. Based on these dimensions, it could be stated that satisfaction during leisure activities plays an important role in continuing to participate in leisure activity [30].

Satisfaction can be expressed as a relationship between expectation from an activity and perceived performance after an activity. If perceived performance is lower than expectation, dissatisfaction from activity might emerge [32]. On the other hand, high leisure time satisfaction of individuals shows that leisure time experience and activities are compliant with individual preference and needs [33]. Francken and Van Raaij [34] (cited in Broughton and Beggs [35]) analyzed perceived differentiation between desired and occurred leisure time activities for individual satisfaction. The study results showed that older individuals and those with an optimistic look had high leisure time satisfaction, while younger individuals and those with a pessimistic look had low leisure time satisfaction. Additionally, in the relevant literature, there is a significant relationship between experience quality and satisfaction For example, Chen and Chen [32] found that there is a significant positive relationship between perceived value and satisfaction. Zins [36] found that there is a significant relationship between consumption experience and satisfaction. Baker and Crompton [37] showed a significant relationship between performance quality and satisfaction. Kim et al. [38] found that perceived value from travel experience has a 
positive effect on satisfaction and travel experience. Additionally, Anderson and Sullivan [39] showed that satisfaction is positively affected by the perceived quality. Accordingly, the following hypothesis is suggested:

\section{H2: There is a significant relationship between experience quality and satisfaction.}

\section{Word of Mouth (WOM)}

Word of mouth communication (WOM) represents unofficial communication of experience, consumers' reviews and recommendation of a product, service or leisure time activity to other potential consumers and information exchange between these consumers $[40,41]$. When evaluated as a source of information, it can be stated that positive word of mouth (WOM) has a strong effect on individuals to decide on a service, product or activity. Additionally, word of mouth communication (WOM) is one of the important strategies to minimize individuals' disharmony after the decision. This is because individuals tend to trust interpersonal communication more than firms [42]. After participating in a recreational activity, satisfaction or dissatisfaction affects individuals' mood, and they inform each other about the experience quality through word of mouth communication (WOM) [43]. Therefore, it is possible to say that word of mouth communication is an attractive way of interpersonal communication. This communication method has no cost or extremely low cost, and it can be considered as one of the important elements to reach larger audience fast by using technologies such as the Internet [44].

Additionally, in terms of businesses, word of mouth can be expressed as an important communication tool for free marketing and persuading potential customers more than ordinary advertising campaigns [45]. Accordingly, individuals' experience quality and satisfaction level during or after service and product use or participation in activity greatly influences word of mouth communication. There are supportive views in the relevant literature. For example, Maklan and Claus [46] stated that customer experience quality has a positive and significant relationship with loyalty, word of mouth communication (WOM) and customer satisfaction. Tripathi [47] found a significant relationship between customer satisfaction and loyalty and word of mouth communication (WOM). Chang and Chui [45] found a significant relationship between consumer experience and word of mouth communication. Additionally, Pappachan and Koshy [48] studied airline services and found that satisfaction was an important mediator between employee service quality and word of mouth communication (WOM). Accordingly, the following hypotheses are suggested:

H3:There is a significant relationship between experience quality and word of mouth communication (WOM). H4: There is a significant relationship between satisfaction and word of mouth communication (WOM).

\section{MATERIAL AND METHODS}

\section{DATA COLLECTION AND SAMPLE}

In this study, 201 individuals participating in the Eskisehir Dance Festival were selected with convenience sampling. The Eskisehir Dance Festival started to be held at the national level in 2013. The number of participants continues to increase year on year. This dance festival is a traditional event that has become one of the most important events in Turkey. The festival includes dances such as Salsa, Bachata and Kizomba. After the festival is completed, two pollsters presented to participants a survey consisting of two sections with a personal interview method. Before participants completed the survey forms, they were informed about this study, and the forms were not given to those who did not want to participate for various reasons. In this sense, it can be stated that participation in the study was voluntary. The pollsters were at the ready while all surveys were being completed, 
and each survey took approximately 8 minutes. Twenty-one surveys among 222 surveys were excluded from analysis due to various mistakes (incorrect or undisciplined coding etc.). In this sense, $91 \%$ return rate was achieved for surveys.

\section{Measurement tOOLS}

A survey form consisting of two sections was prepared for participants based on the study purposes. The first section of the survey form included 31 items to measure views of individuals who participated in the dance festival on "experience motivation", "experience quality", "satisfaction", "word of mouth communication (WOM)". Items that formed the structures were measured with 5-point Likert statements (5-Strongly Agree, 1-Strongly Disagree). To determine demographic properties of the participants, the second section of the survey form consisted of 8 questions. To determine the participants' views on experience quality, statements in the measurement tool developed by Stewart and Cole [19] were adapted. To measure the festival participants' satisfaction with this event, the satisfaction scale developed by Oliver [49] was adapted. Additionally, various measurement tool statements in the related literature on experience motivation, satisfaction and word of mouth (WOM) structures were revised for the purpose of this study. Hambleton and Kanjee [50] stated that the back translation practice is necessary to show equivalency of measurement. Accordingly, all statements considered in this study were translated into Turkish by two academicians and translated back into English to prevent any language problems. As a result, the translated statements were accepted as representation of original items. Babbie [51] suggested that to control clearness of statements in survey forms, individuals in the study sample should control these statements. Accordingly, the survey form was given to a test group of 20 participants. Based on the participant feedback (misspelling, unclear statements etc.), the final survey form was adopted.

\section{Data ANALYsis}

Hair et al. [52] suggested that SEM is a useful method to test multiple causality relationships. The SEM procedure that aims to discover causality relationship between different structures was considered adequate in this study. Based on this information, the study model was analyzed with Amos 20 program based on the SEM practice theoretical principles.

\section{RESULTS}

The characteristics of the sample are described in Table 1, there were 55.7\% females and $44.3 \%$ were males. Additionally, the majority of participants were between $18-25$ years old $(68.2 \%)$ and had undergraduate (71.1\%) education. The majority of participants stated that they participated in the festival with their friends (63.7\%). It was identified that the number of participants that heard about the festival on the Internet (30.3\%) was higher than of those who heard about it through other media tools. This shows that there is a consistent relationship between the study sample and the event type, and that study samples are representative.

Table 1. Demographic characteristics of the participants $(\mathrm{N}=201)$

\begin{tabular}{cccc} 
& & Frequency & $\%$ \\
\hline Gender & Male & 89 & 44.3 \\
& Female & 112 & 55.7 \\
\hline Age & $18-25$ & 137 & 68.2 \\
& $26-35$ & 52 & 25.9 \\
& $26-35$ & 10 & 5 \\
& $36-45$ & 2 & 1
\end{tabular}




\begin{tabular}{|c|c|c|}
\hline & Frequency & $\%$ \\
\hline \multicolumn{3}{|l|}{ Education } \\
\hline High school & 27 & 13.4 \\
\hline Undergraduate & 143 & 71.1 \\
\hline Graduate & 31 & 15.4 \\
\hline \multicolumn{3}{|l|}{$\begin{array}{l}\text { Who did you attend the festival } \\
\text { with? }\end{array}$} \\
\hline Family & 19 & 9.5 \\
\hline Friend & 128 & 63.7 \\
\hline Family and Friend & 14 & 7 \\
\hline Alone & 23 & 11.4 \\
\hline Other & 17 & 8.5 \\
\hline \multicolumn{3}{|l|}{ Income [Turkish Lira (TL)] } \\
\hline $1500<$ & 87 & 43.3 \\
\hline $1501-3000$ & 58 & 28.9 \\
\hline $3001-4500$ & 36 & 17.9 \\
\hline $4501>$ & 20 & 10 \\
\hline \multicolumn{3}{|l|}{$\begin{array}{l}\text { How did you know about this } \\
\text { festival? }\end{array}$} \\
\hline Friend advise & 79 & 39.3 \\
\hline Printed press & 14 & 7 \\
\hline Visual press & 11 & 5.5 \\
\hline Internet & 61 & 30.3 \\
\hline
\end{tabular}

\section{MeAsuRement MOdeL}

Confirmatory factor analysis was applied with AMOS 20 program to total activity experience motivation scale applied in the context of the relevant literature. The experience motivation scale consists of five factors ("experience", "escape", "socializing", "self-improvement" and "entertainment") and 18 statements. The analysis showed that the activity experience scale had acceptable good fit values given in the literature $\left(\chi^{2}=243.806, p=0,000\right.$; $\chi^{2} / \mathrm{df}=1.966 ; \mathrm{GFI}=0.880 ; \mathrm{AGFI}=0.834 ; \mathrm{CFI}=0.920 ; \mathrm{TLI}=0.900 ; \mathrm{IFI}=0.919 ; \mathrm{RMSEA}$ $=0.070)$.

\section{VALIDITY AND RELIABILITY ANALYSIS}

To determine convergent validity of the measurement model, AVE (average variance extracted) values of all structures were calculated, and it was found that all values were above 0.50. Malhotra [53] stated that Cronbach alpha coefficient must not be 0.60 or below to achieve structure reliability. Accordingly, Cronbach's alpha and CR (composite reliability) coefficients were calculated, and all coefficients were above 0.60. Based on this information, it could be said that the experience motivation scale in this study is valid and reliable.

Table 2. Validity and reliability analysis of the experience motivation scale

\begin{tabular}{lc}
\multicolumn{1}{c}{ Structures } & Factor \\
& Loads \\
\hline Sociability (CR: .815), (Cronbach's alpha: .832), (AVE: .595) & .690 \\
I joined with my friends to do something. & .765 \\
I joined in because it was a social event. & .850 \\
I joined in to be with my friends. & \\
\hline
\end{tabular}




\section{Structures}

Loads

Experience (CR: .803), (Cronbach's alpha: .812), (AVE: .503)

I joined because I was curious.

I joined to do something different.

I joined to see new things.

.735

I attended because I was curious about the events.

.680

Entertainment (CR: .771), (Cronbach's alpha: .795), (AVE: .530)

I joined for fun.

.728

I attended because I enjoyed such activities.

.669

I joined to see the fun activities.

.783

Escape (CR: .810), (Cronbach's alpha: .829), (AVE: .520)

I wanted to move away from the daily stress.

I have been involved in boredom.

I joined to add changes to the flow of daily life.

.842

I joined to get away from a routine life.

.646

Personal development (CR: .874), (Cronbach's alpha: .879), (AVE: .636)

I joined to improve myself in dancing. $\quad .686$

I joined to learn something about dance in the professional sense. $\quad .734$

$\begin{array}{ll}\text { I joined in to see my weaknesses of dance and its improve } & .917\end{array}$

I joined to catch up to date with the dance

.834

\section{STRUCTURAL MODEL}

Structural models were created and tested for hypothesis constructed in line with the study purposes. The analysis showed that the presented model was above good fit values given in the literature $\left(\chi^{2}=274.806 \mathrm{p}=0.000, \chi^{2} / \mathrm{df}=1.796, \mathrm{GFI}=0.891\right.$, AGFI $=0.842$, $\mathrm{CFI}=0.930, \mathrm{TLI}=0.917, \mathrm{IFI}=0.927, \mathrm{RMSEA}=0.068)$.

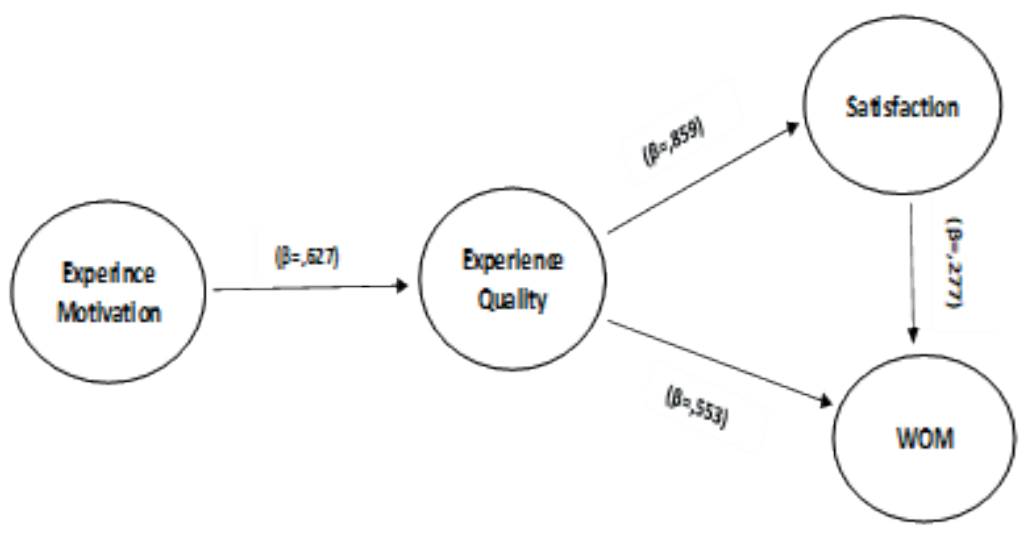

Fig. 1. The structural model for the research hypotheses

Hypotheses constructed in the context of this study were tested for structural models, and all the presented hypotheses were accepted (Table 3). It was shown that experience motivation of individuals who attended the Eskisehir Dance Festival obtained experience quality. Additionally, it was determined that the perceived experience quality had an effect on the participants' satisfaction and WOM behavior. Lastly, in this study, it was determined that the participants' perceived activity satisfaction had a significant effect on WOM behavior. 
Table 3. Path analysis results

\begin{tabular}{lccc} 
Analysis & Path coeffi-cients & T-value & Results \\
\hline H1 Experience quality<---Experience motivation & .627 & 4.13 & Acceptance \\
H2 Satisfaction<--- Experience quality & .859 & 10.36 & Acceptance \\
H3 WOM<--- Experience quality & .553 & 3.54 & Acceptance \\
H4 WOM<--- Satisfaction & .277 & 1.87 & Acceptance \\
\hline
\end{tabular}

\section{DISCUSSION AND CONCLUSIONS}

In this study, a model developed to uncover the relationship between experience motivation, experience quality, satisfaction and word of mouth (WOM) structures of individuals who are active in a dance festival was tested. Acceptable fitness of the suggested model and the acceptance of hypotheses within model structures provided empirical contribution to literature. In our study, it is shown that experience motivations of dance festival participants had an impact on the experience quality. Similar studies in the literature [24, $25,26,27,28$ ] showed that there is a relationship between quality and motivation. Since these studies do not focus on experience motivation and quality, our research fills the gap in the literature. Additionally, parallel results to the current literature on quality and motivation provide evidence that these variables and experience share some similarities.

Analysis of the data obtained from dance festival participants showed that experience quality has significant effects on satisfaction. There are various studies on satisfaction in different fields and with different research methods. Similar studies [32, 36] show that there is significant relationship between satisfaction and quality. Chen and Chen [32] showed that experience quality is one of the most important predictors of satisfaction obtained from an experience. In our study, it was shown that such relationships are similar in a different sample group, namely dance festival participants. Bone [43] showed that satisfaction from a recreational activity has an important effect on WOM behavior. Additionally, Maklan and Claus [46] identified that experience quality is related to WOM. Results obtained from these studies are in line with the results obtained in this study. Various studies that emphasize a relationship between WOM and satisfaction in different disciplines $[40,44]$ can be predictors of results before data analysis. When this subject is evaluated in a broad perspective, it can be seen that there are limited number of studies that have not discovered a relationship between satisfaction and WOM. In this sense, the present results indicate the validity of dance festivals as an important field of recreational activity.

This study has shown that participation in dance festivals can enhance respect for physical activity and improve confidence with respect to both physical activity and social relationships. Participation is also associated with increased respect between age groups and a greater sense of community solidarity, as well as contributes to other aspects of personal and social experience. Therefore, participation in a dance festival as an experience appears to be inherently inter subjective and relational. Friendships are formed or maintained and extended; relatives often share the pride or interest of the young dancers; and intimacy is "rehearsed" in semi-public, structured and playful situations. Our study of responses to dance-festival participation suggests a need to recognize that for individuals there are indeed bodily energies that need to be used, that these have cultural significance, and that the social aspects of "the physical" are paramount. Conclusions regarding the longer term, social or individual health benefits of dance-festival participation await a wider survey. However, our findings suggest that, in terms of health promotion strategies, it is important to rethink on what grounds and in what terms physical activity may be made attractive to the community. As in all other sectors, experience quality in dance festivals is extremely 
important for satisfaction and positive WOM behavior as desired results of these events. In this sense, these results provide important clues that professionals should take precautions to increase experience quality to create event loyalty and increase re-participation. It was shown that perceived values [54] and event image [55] was highly important in this sense. Based on this information, practices by event professionals to increase the perceived value and create event images that comply with the target audience is critically important for such events to achieve desired success results. It could be said that results of this study could provide various managerial recommendations to professionals in this field. The phenomenon of "experience" that has an important place in shifting marketing paradigms forms the basis of our study. In this sense, it is believed that improved experience quality will play an important role in the success of the activity. The obtained results based on our analysis showed that all phenomena (motivation, satisfaction and WOM) under experience quality research were related. This result indicated that recommendations to professionals should focus on experience quality.

\section{LIMITATIONS AND FUTURE STUDIES}

As all other studies, our study has certain limitations in terms of the study sample and similar variables. Limitations of this study provide some recommendations for future studies. In our study, sampling was conducted with convenience sampling due to various reasons (time, money etc.). A new study sample obtained with the probability sampling method could minimize sample errors, and generalizable results might be obtained. In this study, a dance festival organized in Eskisehir is analyzed. Similar studies could be designed for different dance festivals, and results of those studies could be compared with our study. Additionally, new studies that focus on international dance festivals might indicate intercultural change of a related phenomenon. New structures could be added, other than structures considered in this study, models with these new structures could be tested and broader perspective results could be obtained.

\section{ACKNOWLEDGEMENTS}

This study was presented as an oral presentation at the South-Eastern Recreation Research (SERR 2019) Conference on March 24th-26th, 2019 in Athens, Georgia, U.S.A.

\section{REFERENCES}

[1] Wang EST, Chen LSL, Lin JYC, Wang MCH. The relationship between leisure satisfaction and life satisfaction of adolescents concerning online games. Adolescence. 2008; 43(169):177-185.

[2] Horner S, Swarbrooke J. Leisure Marketing. London: Routledge; 2012. https://doi.org/10.4324/9780080478937

[3] Lee B, Shafer C.S. The dynamic nature of leisure experience: an application of affect control theory. J Leisure Res. 2002;34(3):290-310. https://doi.org/10.1080/00222216.2002.11949973

[4] Argan M. Eğlence Pazarlaması [Entertainment Marketing]. Ankara: Detay Yayıncılık; 2007. Turkish

[5] Fraleigh S.H. Dance and the lived body: a descriptive aesthetics. University of Pittsburgh Press; 1987.

[6] Shim H, Shin E, Lim S. What makes us two-screen users? The effects of two-screen viewing motivation and psychological traits on social interactions. Computers in Human Behavior. 2017;75:339-346. https://doi.org/10.1016/j. chb.2017.05.019

[7] Torkildsen G. Leisure and Recreation Management. 4th Edition. New York: Routledge; 1999.

[8] Chen M, Pang X. Leisure motivation: an integrative review. Soc Behav Personal: Int J. 2012;40(7):1075-1081. https:// doi.org/10.2224/sbp.2012.40.7.1075

[9] Kueh Y.C, Abdullah N, Kuan G, Morris T, Naing N.N. Testing measurement and factor structure invariance of the physical activity and leisure motivation scale for youth across gender. Frontier Psychol. 2018;9:1664-1078. https:// doi.org/10.3389/fpsyg.2018.01096

[10] Beard J.G, Ragheb M.G. Measuring leisure motivation. J Leisure Res. 1983;15(3):219-228. https://doi.org/10.1080/ 00222216.1983.11969557

[11] Beggs B, Nicholson L, Elkins D, Dunleavy S. Motivation for participation in campus recreation based on activity type. Recreat Sport J. 2014;38(2):163-174. https://doi.org/10.1123/rsj.2014-0038 
[12] Ho CI, Liao TY, Huang SC, Chen HM. Beyond environmental concerns: using means-end chains to explore the personal psychological values and motivations of leisure/recreational cyclists. J Sustainable Tourism. 2015;23 (2):234-254. https://doi.org/10.1080/09669582.2014.943762

[13] Lee K, Ewert A. Understanding the motivations of serious leisure participation: A self-determination approach. Ann Leisure Res. 2019;22(1):76-96. https://doi.org/10.1080/11745398.2018.1469420

[14] Sheng CW, Chen MC. A study of experience expectations of museum visitors. Tourism Management. 2012;33(1):53 60. https://doi.org/10.1016/j.tourman.2011.01.023

[15] Altunel M.C. Turistlerin beklenti ve deneyimleme kalitesinin tavsiye etme kararına etkisi: müze ziyaretçileri üzerine bir araştırma [The expectation of tourists and the effect of experience quality on recommendation: a research on museum visitors]. Doctoral Dissertation, DEÜ Sosyal Bilimler Enstitüsü; 2013. Turkish.

[16] Oral S, Çelik A. Türkiye'yi ziyaret eden turistlerin estetik deneyimleri üzerine bir araştırma [Research on Aesthetic experience of tourists who visited Turkey]. İşletme Araştırmaları Dergisi. 2013;5(4):170-190. Turkish.

[17] Oliver R.L. Satisfaction: a behavioral perspective on the consumer. Armonk, NY: ME Sharpe Inc.; 2010.

[18] Zeithaml V.A. Consumer perceptions of price, quality, and value: A means-end model and synthesis of evidence. J Marketing. 1988;52(3):2-22. https://doi.org/10.1177/002224298805200302

[19] Stewart WP, Cole DN. Number of encounters and experience quality in Grand Canyon backcountry: Consistently negative and weak relationships. J Leisure Res. 2001;33(1):106-120. https://doi.org/10.1080/00222216.2001.11949933

[20] Raake A, Egger S. Quality and quality of experience. In: Möller S, Raake A, editors. Quality of experience: advanced concepts, applications and methods. Switzerland: Springer International Publishing; 2014: 3-9.

[21] Lemke F, Clark M, Wilson H. Customer experience quality: an exploration in business and consumer contexts using repertory grid technique. J Academy Marketing Sci. 2011;39(6):846-869. https://doi.org/10.1007/s11747-010-0219-0

[22] Paul R, Ponnam A. Teaching customer experience quality and its significance in retail management: A role playing game using Chinese puzzle 'tangram'. Decision Sci J Innovative Educ. 2018;16(2):126-139. https://doi.org/10.1111/ dsji.12147

[23] Driver B.L, Tocher S.R. Toward a behavioral interpretation of recreational engagements, with implications for planning. In: Driver BL, Editor. Elements of outdoor recreation planning. University of Michigan Press; 1970, 9-31.

[24] Ahmed I, Nawaz M.M, Ahmad Z, Ahmad Z, Shaukat MZ, Usman A, Ahmed N. Does service quality affect students performance? Evidence from institutes of higher learning. Afr J Business Manag. 2010;4(12):2527-2533.

[25] Sobral D.T. What kind of motivation drives medical students' learning quests? Med Educ. 2004;38 (9):950-957. https:// doi.org/10.1111/j.1365-2929.2004.01913.x

[26] Kılıç R, Keklik B. Sağlık çalışanlarında iş yaşam kalitesi ve motivasyona etkisi üzerine bir araştırma [A research on the quality of work life and its effect on motivation in healthcare professionals]. AKÜ İİF Dergisi, $2012 ; 14$ (2): 147-160. Turkish.

[27] Sasongko T. The role of employee motivation on the relationship between HRM practices and service quality in healthcare organization. JEMA. 2018;15(01):1-11. https://doi.org/10.31106/jema.v15i01.782

[28] Subrahmanyam A. Relationship between service quality, satisfaction, motivation and loyalty: A multi-dimensional perspective. Qual Assur Educ. 2017;25(2):171-188. https://doi.org/10.1108/QAE-04-2013-0016

[29] Freire T, Teixeira A. The influence of leisure attitudes and leisure satisfaction on adolescents' positive functioning: The role of emotion regulation. Frontiers Psychol. 2018;9:1-12. https://doi.org/10.3389/fpsyg.2018.01349

[30] Elkins DJ, Beggs BA, Choutka E. The contribution of constraint negotiation to the leisure satisfaction of college students in campus recreational sports. Recreat Sport J. 2007;31(2):107-118. https://doi.org/10.1123/rsj.31.2.107

[31] Beard JG, Ragheb MG. Measuring leisure satisfaction. J Leisure Res. 1980;12(1):20-33. https://doi.org/10.1080/00 222216.1980.11969416

[32] Chen CF, Chen FS. Experience quality, perceived value, satisfaction and behavioral intentions for heritage tourists Tourism Management. 2010;31(1):29-35. https://doi.org/10.1016/j.tourman.2009.02.008

[33] Pinquart M, Schindler I. Change of leisure satisfaction in the transition to retirement: A latent-class analysis. Leisure Sci. 2009;31(4):311-329. https://doi.org/10.1080/01490400902988275

[34] Francken DA, Van Raaij WF. Satisfaction with leisure time activities. JLeisure Res. 1981;13(4):337-352. https://doi. org/10.1080/00222216.1981.11969498

[35] Broughton K, Beggs BA. Leisure satisfaction of older adults. Activ Adapt Aging. 2007;31(1):1-18. https://doi. org/10.1300/J016v31n01_01

[36] Zins A.H. Consumption emotions, experience quality and satisfaction: a structural analysis for complainers versus non-complainers. J Travel Tourism Marketing. 2002;12(2-3):3-18. https://doi.org/10.1300/J073v12n02_02

[37] Baker DA, Crompton JL. Quality, satisfaction and behavioral intentions. Ann Tourism Res. 2000;27(3):785-804. https:// doi.org/10.1016/S0160-7383(99)00108-5

[38] Kim H, Woo E, Uysal M. Tourism experience and quality of life among elderly tourists. Tourism Management. 2015 46:465-476. https://doi.org/10.1016/j.tourman.2014.08.002

[39] Anderson EW, Sullivan MW. The antecedents and consequences of customer satisfaction for firms. Marketing Sci. 1993;12(2):125-143. https://doi.org/10.1287/mksc.12.2.125

[40] Lee Y. Relationship quality and its causal link to service value, satisfaction, and word-of-mouth. Services Marketing Quart. 2016;37(3):171-184. https://doi.org/10.1080/15332969.2016.1184541

[41] Cho I, Park H, Kim JK. The relationship between motivation and information sharing about products and services on facebook. Behav Information Tech. 2015;34(9):858-868. https://doi.org/10.1080/0144929X.2014.988177

[42] Ng S, David ME, Dagger TS. Generating positive word-of-mouth in the service experience. Managing Service Qual: Int J. 2011;21(2):133-151. https://doi.org/10.1108/09604521111113438

[43] Bone, P.F. Determinants of word-of-mouth communications during product consumption. ACR North American Advances. 1992; 19: 579-583. 
[44] Trusov M, Bucklin RE, Pauwels K. Effects of word-of-mouth versus traditional marketing: findings from an internet social networking site. J Marketing. 2009;73(5):90-102. https://doi.org/10.1509/jmkg.73.5.90

[45] Chang HC, Chiu PY. Innovative marketing in professional baseball teams. Service Industr J. 2016;36(11-12):576-594. https://doi.org/10.1080/02642069.2016.1255726

[46] Maklan S, Klaus P. (2011). Customer experience: are we measuring the right things? International Journal of Market Research. 2011; 53 (6): 771-772. https://doi.org/10.2501/IJMR-53-6-771-792

[47] Tripathi G. Customer satisfaction and word of mouth intentions: Testing the mediating effect of customer loyalty. Journal of Services Research; 2017; 17 (2): 1-16.

[48] Pappachan J, Koshy M.P. Moderation effect of travel context in the linkage among employee service-quality, satisfaction and trust on word-of-mouth of airline passengers in india. Amity J Marketing. 2016;1(1):75-92.

[49] Oliver R. L. Satisfaction: a behavioral perspective on the consumer. New York: Irwin-McGraw-Hill; 1997.

[50] Hambleton, R.K., Kanjee, A. Enhancing the validity of cross-cultural studies: improvements in instrument translation methods. Paper presented at the annual American educational research association conference, Atlanta, GA; 1993

[51] Babbie E. The practice of social research, Vol. 8. CA: Wadsworth, Belmont;1998

[52] Hair JF, Tatham RL, Anderson RE, Black W. Multivariate data analysis. Vol. 6, New Jersey: Pearson Prentice Hall; 2006.

[53] Malhotra NK. Questionnaire design and scale development. In: Grover R, Vriens M, editors. The handbook of marketing research: uses, misuses, and future advances. 2006; 176-202.

[54] Moon K, Ko Y, Connaughton D, Lee J. A mediating role of destination image in the relationship between event quality, perceived value, and behavioral intention. J Sport Tourism. 2013;18(1):49-66. https://doi.org/10.1080/14775 085.2013.799960

[55] Jin N, Lee S, Lee H. The effect of experience quality on perceived value, satisfaction, image and behavioral intention of water park patrons: new versus repeat visitors. Int J Tourism Res. 2013;17(1):82-95. https://doi.org/10.1002/jtr.1968 